\title{
Aprendiendo a leer y a escuchar
}

\section{JUAN CARLOS RODRÍGUEZ}

\author{
Universidad de Granada \\ España
}

\section{A.- DE DISCÉPOLO AL BOLERO: DE LA LEYENDA AL MITO.}

I

\section{Discépolo y otras islas}

1.- Cuando Discépolo llegó al tango, el tango estaba ya hecho.

Había pasado de su época legendaria a su época mítica. El tango se había convertido en mito. Y el mito tiene un problema básico. Pierde su contacto con la realidad para transmutarse a sí mismo en la expresión de esa realidad. Por ejemplo: la Guerra de Troya no existió jamás (sí existieron múltiples guerras digamos "comerciales" en ese mundo). Y de ahí surgieron las leyendas que se condensaron en el mito: el mito de la Ilíada ha convertido en real la guerra de Troya. Lo mismo dice Borges respecto a la "Fundación mítica" de Buenos Aires: "A mí se me hace cuento que empezó Buenos Aires/ la juzgo tan eterna como el agua y el aire". Y algo similar ocurre con respecto al tango. Las brumas que rodean los orígenes del tango aún nos dejan entrever algunas cuestiones que suenan a verdad. Incluso las primeras letras del tango, señala Borges, eran verdaderamente eróticas y rozaban incluso lo pornográfico. Luego se irían haciendo cada vez más sentimentales y así se habrían ido deshilachando. En cierto modo esta es una de tantas generalizaciones arriesgadas que suele hacer 
Borges. Y ello a partir de su convicción fundamental de que el tango había tenido que nacer en el burdel. Las contradicciones y los datos concretos son demasiado fuertes como para no poner en duda esas generalizaciones de Borges, pero esto ya lo he señalado en otra parte ${ }^{1}$. De hecho, el tango nace en el suburbio y en los barrios de emigrantes y su carácter marcadamente erótico, que no perderá nunca, proviene de la “oscura gente", esa gente que no tenía otra cosa a la que agarrarse que al propio cuerpo y al cuerpo de su pareja. Por eso el tango al principio fue baile. En los corrales, en los "conventiyos", en los bailes populares y, por qué no, también en el burdel que forma parte de la configuración del barrio. "El tango empezó en los pies”, dice Discépolo, “y luego se apoderó del alma porteña hasta llegar a flor de labios”. Es obvio que el tango fue primero baile y después se convirtió en letra. Pero en la afirmación de Discépolo hay un matiz inconsciente decisivo: nos dice que el tango no sólo se convirtió en letra sino en el alma porteña, en su expresión. Esto es, Discépolo nos está narrando aquí tanto el paso del baile a la letra como el paso de la leyenda al mito. Incluso más: nos está narrando de modo paralelo la inevitable transformación del tango desde su modo de ser canción del suburbio hasta ser esa expresión incrustada en el centro de la gran ciudad y desparramada luego desde ahí. Se trata de una especie de inversión en los lugares de tango y por tanto en su forma de realización. Cafetín de Buenos Aires, uno de los tangos claves de Discépolo, es ya un café de artistas y bohemios, en absoluto el "boliche" o el "bulín" (la pequeña taberna/almacén) del barrio lejano. Homero Manzi, quizás el otro gran genio del tango de esos años (habría también que hablar de los hermanos Expósito, por supuesto), un Manzi que tantas cosas compartió con Discépolo, incluidas la edad y la amistad, lo escribió mejor que nadie en sus versos. Si Celedonio Flores (el "negro Cele") convirtió en 1933 el cruce de Corrientes y Esmeralda, dos esquinas básicas, dos lugares centrales del Buenos Aires de aquella época, en mito del tango urbano, por el contrario, el tango Sur, de Manzi, nos habla de los barrios de su juventud, San Juan y Boedo antiguo, un mundo que es ya sólo una nostálgica elegía: "Todo ha muerto. Ya lo sé”.

Poco a poco el barrio se había convertido en la ciudad y el legendario tango barriobajero se había transformado en el mito-alma de toda la ciudad porteña. Y esta es

\footnotetext{
${ }^{1}$ Cfr. J.C.R., "Del primer al último tango", en Granada Tango, ed. La Tertulia/ Euroliceo, Madrid, 1996 ( $2^{\mathrm{a}}$ ed.), pp. 43-133, y en De qué hablamos cuando hablamos de literatura, Comares, Granada, 2002, pp. 293-398.
} 
la primera clave que necesitamos anotar para trazar algo acerca de la relación de Discépolo y el tango. Se trata de ese paso de la leyenda al mito, que habíamos esbozado desde el principio. Pues es ahí donde aparece Discépolo, en las dos décadas prodigiosas del tango, entre los años veinte y los años cuarenta de ese siglo XX que él cantaría luego en Cambalache.

2.- Sólo que entre la leyenda y el mito hay una diferencia abismal. No sólo cuantitativa sino en especial cualitativa. En el legendarismo del tango de finales del XIX y principios del XX las historias que se cuentan con los pies, con el baile, con la música (incluida la tardía aparición del bandoneón) y luego con letras, muchas de las cuales plausiblemente desconocemos, lo único que queda claro es la dislocación, el no-lugar de los emigrantes. La ley de emigración se había establecido desde muy pronto (en la Constitución de 1853), pero luego se fue restringiendo cada vez más, (por ejemplo la Ley de Residencia de 1904 o la llamada "Ley Mordaza" de 1919). Se prometían trabajos y tierras que ya no existían o que ya no se podían repartir. Repito que la oscura gente no tenía otra cosa a la que aferrarse que a la esperanza de su vida subjetiva, a la pervivencia a través del cuerpo de cada día. Digamos que la leyenda del tango nos lleva así a supuestos sociológicos y psicológicos inevitables: el tango originario no es sólo la manera de agarrarse al cuerpo sino la manera de arraigarse. Aunque fuera en aquellas calles del suburbio donde surgieron sus primeros signos claves. No sólo las figuras de la vieja, o sea de la madre, del bulín o del propio barrio, sino el límite entre la legalidad y la ilegalidad, la astucia para ser o no ser, para sentirse libre como un malevo -un supuesto fuera del límite- o por el contrario sentirse como un gil -el imbécil que está dentro del límite-. Muy pronto los hijos de los emigrantes aprenderían que el sistema establece un límite que está siempre dentro del límite. O de otro modo: que no hay un afuera del sistema. De ahí quizá la burla del malevo que hace Discépolo explícitamente en su tango Malevaje. Pero se trata ya de una segunda o tercera generación de emigrantes que se han convertido en proletarios, en pequeño burgueses e incluso algunos en empresarios del centro. Los años veinte-cuarenta fueron decisivos para Argentina, y en especial la crisis capitalista de los años 29/30 la había pagado muy fuertemente. El tratado de Otawa de 1932, entre el Reino Unido y los países de su Commonwelth, dejó a Argentina "aislada". Y de este modo junto al mito del tango, que se había convertido en incontrovertible, ahí surgió el otro mito decisivo, es decir, el del 
nacional-populismo argentino. El viejo liberalismo conservador, el de las oligarquías del siglo XIX se había esfumado dejando paso a nuevos partidos que se aferraban a la protección aduanera y a la explotación de carne congelada o de cereales a través de una nueva burguesía atada, sin embargo, a las ganancias del mercado interior y que se resistía a expandirse hacia otros mercados más amplios -o no podía hacerlo-. El nacional-populismo era un efecto evidente de esas situaciones de crisis, que penetraban especialmente en aquella emigración transformada ya en proletariado $-\mathrm{O}$ en pequeñoburgueses, trabajadores de "cuello blanco"- que bajo el mito del nacionalismo intentaba encontrar sus señas de identidad. (como los "cabecitas negras" del interior que llegaban a Buenos Aires. Maradona sería finalmente el símbolo básico de esos “cabecitas negras").

Irigoyen fue quizá, en los años 20, el gobernante simbólico de ese mundo, mientras que los sindicatos obreros se disolvían en los famosos "gremios amarillos" de los que se aprovecharía Perón a través de su largo primer mandato. La izquierda argentina apenas existió, pues ni el partido radical ni los partidos comunista o socialista supieron encarrilarla. Mientras, Irigoyen iba entregando progresivamente el poder a los militares hasta que llegó, en los años 30, la dictadura del general Uriburu (con el apoyo suicida de la izquierda) y posteriormente la "dictablanda" militar/burguesa de Agustín Justo, cuando se aparcaron, por el momento, los proyectos literalmente fascistas de Uriburu. Lo que quedó de aquellos años de lucha, en los que las masas de trabajadores, desconcertadas, no sabían adónde dirigirse, (salvo por el camino del nacionalismo "infatuado", que era el gran señuelo de la nueva burguesía), acabó confluyendo en el Peronismo. Las luchas de la época fueron muy fuertes pese a todo y es curioso que "todo" volviera a reordenarse no sólo bajo la sombra del caudillo, sino bajo la sombra conjunta del familiarismo pequeño burgués, la sombra del padre Perón y de la madre Evita, la de los “descamisados" (un término de origen anarquista), la de la mística populista que inútilmente los intereses dominantes intentaron hacer retornar con Isabelita y el brujo López Rega, una payasada que culminaría con la tiranía de los “milicos". Es sintomático que tanto Enrique Santos Discépolo como Homero Manzi acabaran su vida apoyando al peronismo, incluso desde la radio. Pues, como decimos, el mito del tango se había ido haciendo inseparable de la mitología populista del nacionalismo argentino. Pero hay diferencias: mientras la burguesía y la oligarquía de 
los años veinte y treinta sí pagaba a sus militares, los milicos de los años setenta, al igual que la economía argentina, estaban ya controlados por los yankis, al igual que lo estuvo Pinochet en Chile. Pero el sentido gremial y la soberbia autónoma y la ceguera de los propios milicos les llevó a creerse autónomos y a intentar hacer renacer el nacional populismo con la guerra de las Malvinas ${ }^{2}$. Lógicamente aquella estupidez asesina, prolongación del asesinato generalizado y de los desaparecidos, iba a propiciar un efecto completamente contrario al buscado: el nacional-populismo acabó por desaparecer (hasta cierto punto: sigue siendo tan fuerte como la "religión del fútbol"), en un proceso que quizá había comenzado ya mucho antes. Y con la desaparición de ese mito nacional-popular, el mito tanguero comenzó a tambalearse también.

3.- Y acaso el tango se sustentó en un nuevo recorrido: al dejar de ser mito se transformó en una especie de nueva leyenda. Algo que de algún modo no podía dejarse perder (su "aroma de leyenda", como diría Valle-Inclán), que se tenía que recuperar con un nuevo frescor. No ya su insoportable necesidad de ser mito, sino más bien el aroma legendario de algo que retorna siempre nuevo. Porque mientras el mito es indestructible y maléfico, en tanto que impide la autorreflexión sobre él y sólo permite la identificación con él, la leyenda, en cambio, es flexible, incita a la reflexión crítica, tiende hacia la afiliación y hacia la selección. Digamos: una cosa es el Ulises de La Odisea y otra cosa el Ulysses de Joyce construido con retazos legendarios: 24 horas en Dublín.

Quizá por eso si la palabra mágica de Irigoyen, Perón o los militares fue siempre la palabra "Pueblo"3, es decir, la negación de la explotación cotidiana y de la división en clases y estratos (dentro de cada "pueblo" o "nación"), cuando el tango empezó a recuperarse a partir de los años ochenta (y en el nuevo contexto digamos

\footnotetext{
${ }^{2}$ Es verdad que las "Asociaciones Militares" eran auténticas empresas de autofinanciación y de riqueza para los jefes. Cfr. El magnífico libro de Miguel Ángel García: Peronismo. Desarrollo económico y lucha de clases en Argentina. Ed. Mario Acosta, Barcelona, 1980.

3 "Más alpargatas y menos libros" era la consigna de los trabajadores peronistas... Pero el peronismo sigue gobernando en Argentina, de otra manera. Sobre la problemática de fondo del "peronismo", antes y después de Eva Perón, debe verse el magnífico "reportaje-novela" de Tomás Eloy Martínez: Santa Evita, ed. Punto de Lectura, Madrid, 2006. Y por supuesto, de Osvaldo Soriano: No habrá más penas ni olvido, Ediciones B, Barcelona, 1987 (existe una edición digitalizada). Los dos autores, desgraciadamente ya fallecidos, rinden homenaje a Rodolfo Walsh, -un peronista "distinto", asesinado por los "milicos"- y al no menos magnífico Juan Gelman (poeta al que he "elegido" en alguna antología alguna vez), al que tanto debo "conversacionalmente" y que tuvo la delicadeza de citarme en su discurso de recepción del Premio Cervantes en 2007.
} 
posmoderno mundial), quizá la palabra mágica que nos obsesionó en el tango y que seleccionamos en el tango fue otra completamente distinta. Podría decirse que la nueva palabra elegida fue la palabra Uno, el inesperado título de un tango que encontrábamos en Discépolo.

No se trataba, creo, de aludir al tan traído y llevado subjetivismo posesivo de la posmodernidad, del aferramiento únicamente a lo privado, sino de una cuestión mucho más de doble filo. Lo que la posmodernidad de los ochenta nos ha dejado como cenizas ha sido algo que ya estaba esbozándose en ella misma: no el canto al yo sino precisamente la puesta en cuestión del yo.

Lo que podríamos llamar un proceso a la individualización, esa individualización antes tan segura o estable y ahora convertida en astillas y fragmentos. ¿Y qué mejor proceso a la individualización que nombrar al yo a través del no-yo, es decir, nombrarse a sí mismo como "uno"? "Uno" es el impersonal por definición para definir a la persona. El "uno" es como el "se": ambos impersonales abstractos que intentan decir algo concreto. ¿Quién es uno? Lo sintomático es que uno no existe porque, dice Discépolo, "Uno se ha quedao sin corazón”, y sin corazón (id est: sin imagen propia) uno es nadie.

Este proceso a la individualidad es lo que más sorprende en los tangos de Discépolo. He dicho al principio que Discépolo llegó al tango cuando el tango ya estaba hecho. De modo que sus obras tienen que introducirse en unos marcos ya establecidos, en unas categorías ya institucionalizadas. Pero la clave radica más bien en el síntoma que acabamos de señalar. Es decir, en el hecho de que Discépolo introdujera por primera vez no la relación entre las palabras mágicas "yo y pueblo", o "yo y barrio" o "yo y malevaje" (cosa que también hace, obviamente), sino en la inesperada aparición de ese impersonal al que acabamos de aludir, al impersonal uno, acompañado incluso de una autorreflexión también impersonal como el se ("uno se ha quedao") 4 .

Ese "se" o ese "uno" jamás habían existido en el tango. Sólo acaso en una de las otras islas contemporáneas suyas, en especial el otro escollo increíble en la maraña del tango, o sea, Homero Manzi. Manzi fue capaz de convertir ese uno en un nombre

\footnotetext{
${ }^{4}$ Digamos, un se que oscila, en tensión, entre la radical singularidad (de la que hablarían los psicoanalistas lacanianos: lo singular del sujeto) y la voz coral de que hablaría el simbolismo individual de Marx y el propio Freud: lo simbólico que produce al yo).
} 
propio absolutamente desdibujado, visto desde afuera, el nombre de Malena. La historia de Malena se ha narrado así:

Homero Manzi volvía de México en 1941. Había viajado con Discépolo y Tania. De regreso pasó por San Pablo, en el Brasil. Recalada nochera en un peringudín y una voz extraña que desafina tangos. Es la de Malena de Toledo, esposa del cantor mexicano Genaro Salinas que encontró trágica muerte en Venezuela. Un tango, aunque desafinado, si se escucha de fronteras afuera, es siempre un estiletazo. Manzi vuelve al hotel con aquella voz de sombra golpeándole los oídos y trasfiere su emoción a los versos de Malena. Cuando llega a Buenos Aires se los confía a Lucio Demara. En pocos minutos, sobre la mesa de un café, en Acevedo y Libertador, el autor de Daniel concluye de garabatear un pentagrama. En enero de 1942 su orquesta estrena Malena en la radio El Mundo y Juan Carlos Miranda canta por primera vez los versos de Manzi. Luego, cuando Lucas Demare dirige el viejo Hucha (Artistas Argentinos Asociados, 1942), se incluye Malena. Se lo ve cantar a Osvaldo Miranda, pero la voz es la de su casi homónimo Juan Carlos Miranda. Poco más tarde, Francisco Fiorentino, con la orquesta de Aníbal Troilo, convierte a Malena en un tango clásico; es decir, en un tango inmortal. ${ }^{5}$

4.- O quizá también Homero Expósito, en el que los temas de Discépolo se hacen todavía más patentes, como la ciudad masiva con "los sueños de un millón de obreros" o bien la subjetividad indecisa en la metáfora básica de que hay "hombres que piensan de perfil”.

Expósito lleva a Discépolo consigo en otras imágenes no menos radicales, como por ejemplo cuando señala lo peligroso que es "matar por la espalda al amor/ sin tener otra piel donde ir". O por poner otro ejemplo: "Primero hay que saber sufrir/ después amar, después partir/ y al fin andar sin pensamiento”. Ese andar sin pensamiento es obviamente el símbolo del no-pensar, la clave de Discépolo. Se ha escrito mucho, a la inversa, de las influencias que recibió Discépolo, por ejemplo la de Roberto Arlt, de apellido casi impronunciable, como el propio Arlt decía (añadiendo que el nombre de su padre era aún más impronunciable, pero "presumiendo", en falso, de que ese padre había sido alumno de Freud en Viena). En 1929-30 Arlt ganó el premio nacional de novela argentina por su obra Los siete locos, claramente influenciada por El hombre que fue jueves, de Chesterton, que fue traducida al castellano en 1922 por Alfonso Reyes (para la editorial Calleja, de Madrid) y que tiene el mismo argumento que la de Arlt: siete anarquistas que intentan un complot para derribar al gobierno del país, y cada uno de ellos lleva el nombre de un día de la semana. Arlt vuelve grotesco este argumento y los siete locos del complot llevan

\footnotetext{
${ }^{5}$ José Gobello y Jorge A. Bosío, Tangos, letras y letristas, Plus Ultra, Buenos Aires, 1979, p.141.
} 
nombres como "el Astrólogo", etc. Curiosamente Arlt, proclive al individualismo anarquista, borra de un plumazo los nombres de los personajes, excepto el muy brumoso del protagonista. Pero quizás sean las colaboraciones periodísticas diarias de Arlt, recogidas en Aguafuertes porteñas, las que más se hayan asimilado a Discépolo. También otro nombre aparece ahí, el de Raúl Scalabrini Ortíz, autor de El hombre que está solo y espera, un libro simbólico sobre las señas de identidad argentinas, en el que Scalabrini trata de separarse de la influencia británica de la alta burguesía (y por eso escribirá también Historia de los ferrocarriles argentinos, la gran inversión inglesa en el país, e incluso Política británica en Argentina). También se ha hablado de Leopoldo Marechal (Adán Buenosayres, Antígona Vélez, etc.) o de Eduardo Mallea en esta mezcla de nacionalismo/ populismo/ culturalismo que rodea a Discépolo ${ }^{6}$.

5.- Pero dejándonos de estas posibles influencias lo cierto es que se ha escrito bastante, y bastante bien sobre Enrique Santos Discépolo Deluchi ${ }^{7}$. Hijo de un músico napolitano, Discépolo vivió exactamente cincuenta años, de 1901 a 1951. Si se le llamó Discepolín "el filósofo" fue quizá por esa nueva mirada sobre la subjetividad o quizá por su famosa definición del tango: "El tango es un pensamiento triste que se baila". La introducción del término pensamiento en el ámbito del tango es sin duda lo que le valió el calificativo de "filósofo", así como la introducción de esa brumosa subjetividad del uno impersonal que siempre se percibía en sus textos y que extrañaba. Su primer tango se tituló Bizcochito, en 1925, pero fue al año siguiente, al componer Qué vachaché, cuando Discépolo parece encontrar el tono que luego inscribirá plenamente en sus tangos. El fracaso estruendoso de Qué vachaché, en su estreno en Montevideo, nos indica claramente ese cambio de atmósfera. El propio Discépolo nos señala que el público pensó que "eso" no era un tango. De hecho es un diálogo dramático donde un personaje calla, como ausente del escenario, mientras que el otro personaje habla sin parar. En realidad es una bronca que una mujer le lanza a su pareja: ya está bien de hacerte el engreído, el engrupido, tú no vas a cambiar el mundo, basta de hablar de

\footnotetext{
${ }^{6}$ Borges, con su acostumbrada mala uva, dijo de Mallea, su compañero de estudios: “Ah, sí, Eduardito... Qué bellos títulos. La bahía del silencio, Todo verdor perecerá... Pero ¿por qué esa manía de añadirles luego un texto?"

${ }^{7}$ Cfr. Por ejemplo, Álvaro Salvador, "La letra con tango entra: la poesía de Enrique Santos Discépolo", en VV-AA. Homenaje a la profesora María Dolores Tortosa Linde, Universidad de Granada, Granada, 2003.
} 
moral, puesto que la única moral es el dinero. Plata, plata, plata es la palabra que se repite obsesivamente en el tango, pues eso es lo único que de verdad cuenta. Para concluir: “¿Qué vachaché? ¡Si hoy ya murió el criterio!/ vale Jesús lo mismo que un ladrón”. No hace falta ser un lince para darse cuenta de que el sentido global del texto y especialmente este final nos remiten directamente a la visión del mundo que luego se nos va a dar en Cambalache. Pero el tono entre desgarrado y satírico de este diálogo dramático de Qué vachaché llevó pronto a casi todo el mundo, (incluido el propio Discépolo), a hablar de un tema que hoy es bien conocido. Es decir, el tema del "grotesco", el género teatral con el que había triunfado su hermano Armando, catorce años mayor que él, y con el que Enrique vivía desde que murieron sus padres.

Autores como David Viñas y Claudia Kaiser-Lenoir han estudiado ampliamente esta problemática del grotesco teatral. Y en el libro que escribimos Álvaro Salvador y yo sobre literatura hispanoamericana se recuerda cómo el entremés del siglo de oro español se transforma en sainete en el siglo XVIII, sobre todo con Don Ramón de la Cruz y una obra de título clave: Manolo, tragedia para reír y sainete para llorar. Evidentemente ahí está forjándose ya un grotesco que obviamente Goya llevaría al extremo. Pero a la vez se señala cómo en los sainetes de Don Ramón de la Cruz funciona otra cuestión teatral básica: la importancia de las acotaciones escénicas (claramente explicitadas por primera vez en el teatro español), "acotaciones" que alcanzarán su plenitud en los esperpentos de Valle Inclán. Es obvio que el "grotesco" teatral porteño no tiene nada o casi nada que ver con los esperpentos de Valle ${ }^{8}$, pero también es cierto que en las acotaciones que Armando Discépolo coloca en sus obras hay una descripción de personajes y situaciones que parece indudable que Enrique trasladaría luego a la letra de sus tangos.

6.- El éxito del grotesco en Buenos Aires proviene sin duda del éxito de los sainetes que llevaban allí las compañías españolas tanto con las obras de Arniches como con las zarzuelas más o menos satíricas al estilo de La Gran Vía. Este estilo satírico llevó a cambiar en gran medida el modelo del melodrama social-trágico (también con ribetes anarquistas) de Florencio Sánchez, como se sabe el primer gran autor teatral argentino. Salvo que el grotesco de Armando Discépolo no proviene sólo de los sainetes

\footnotetext{
${ }^{8}$ Cfr. J.C.R. y Álvaro Salvador, Introducción al estudio de la literatura hispanoamericana. Madrid: Akal, $2^{a}$ ed., 1992 y J.C.R. De qué hablamos cuando hablamos de literatura, Op. Cit.
} 
españoles sino también del grotesco de los arlequines italianos y desde luego de un planteamiento dramático distinto. Si Don Ramón de la Cruz había convertido al sainete en la inversión de la tragedia neoclásica, si los arlequines italianos provocaban a la vez la risa y la lágrima, si los sainetes al modo de Arniches procuraban reflejar -cuando no crear- el habla y las situaciones cotidianas de las clases subalternas, obviamente esa mezcla tenía que funcionar muy favorablemente en el Buenos Aires de los veinte primeros años del siglo. Si nos fijamos, en la mayoría de las obras de Armando Discépolo, como Mustafá, Mateo, Stéfano, Cremona o Relojero, en ese escenario de sainete donde la risa y la lágrima se juntan, se despliega por un lado la situación de los emigrantes que apenas saben hablar castellano y que tienen una especie de moral del deber y del trabajo honrado, una moral del buen roussoniano pequeño burgués, pero que por otro lado pronto se dan cuenta de que su reloj está atrasado o de que El Organito (como se tituló la obra que escribieron los dos hermanos Discépolo en 1925) ya no vale. La segunda generación, (la de los hijos y las hijas de emigrantes), vive ahora en el ámbito descabalado de un nuevo mundo donde sólo importa el ganar dinero fácil y pronto. Ese mundo semidelincuente del malevaje o de la prostitución cara (como la liberada hija Nené de Relojero) y de la corrupción política y moral que lo anega todo. El grotesco dramático se impone porque implica una realidad con la que cualquiera puede identificarse, precisamente porque no hay individuación posible ni fija. Si gran parte del éxito del cine mudo (que tanto impresionaba a Borges cuando aún podía ver) se debe quizá al hecho de que, aparte de la fascinación de las imágenes, permitía barrer las fronteras del idioma, el grotesco, por el contrario, se inserta en esas fronteras lingüísticas. De algún modo ahí se acabará configurando el lunfardo, el lenguaje casi por excelencia del tango. Lo curioso es que los tangos de Discépolo son transparentes, poco lunfardianos, pero eso sí, se presentan como monólogos o diálogos dramáticos, como escenas teatrales, que de algún modo distancian "al tango dentro del tango", en sus líneas de sombra interiores. Así llegó el gran éxito de 1927 el que consagró definitivamente al flaco Discépolo: Esta noche me emborracho. Aquí entra quizá otro elemento básico, lo que en Buenos Aires se llamaba la cachada, es decir, la burla. Dice Discépolo: "el porteño tiene el pudor de sus emociones y de sus sentimientos. Por eso no los exterioriza. Trata de despistar cuando habla. Es el temor a la cachada. Y para que no lo cachen los demás, se cacha él mismo...”. Algo de esto hay, sin duda, en Esta 
noche me emborracho, sólo que la "auto-burla" es una llaga brutal en sí misma. Discépolo solía decir que componer un tango le costaba más que escribir sus obras teatrales, pero la imagen era la misma: se le ocurría una idea y se metía en la piel del intérprete para escenificarla. Es una representación un tanto distanciada, como digo, y así en Esta noche me emborracho se nos presenta la disolución de la personalidad, la des-individuación hasta el límite de la locura. Pero se nos cuenta la historia de un día, en el mismo hoy, en el mismo día que esa historia ha ocurrido, desde la madrugada hasta la noche. Los tres adjetivos iniciales constituyen un verso prodigioso que todo el mundo recuerda: "Sola, fané, descangayada". Aunque fané sea de origen francés y descangayada o derrumbada es un galleguismo, esos tres adjetivos forman parte del lenguaje normal de los argentinos y su conjunción es un paradigma del tango. El texto continúa en el presente mismo de la narración: "la vi esta madrugada/ salir de un cabaret". Se trata, como decimos, de esta misma madrugada de hoy, no la de ayer o la de otro día. Es el efecto del presente, (de alguien que vive aún bajo ese efecto) lo que aquí se nos cuenta. Sólo que ese "alguien" ve en el derrumbe físico de la mujer su propio derrumbe. Son dos espejos rotos por todos lados. La descripción de la mujer que se ve en el alba es grandiosa y conviene recordarla: disfrazada de jovencita provocativa ("vestida de pebeta"), y sin embargo flaca, con dos cuartas de cogote y esa inolvidable "percha en el escote” (¿para qué lleva escote?) "bajo la nuez”; chueca (o sea, con las piernas torcidas) y sin embargo aún coqueteando su desnudez. Es como la metáfora de un gallo vencido, desplumado, que pese a todo aún compadrea mostrando su piel (su “cuero") picoteado. Sólo que evidentemente esa metáfora del gallo nos lleva a otra parte: ese gallo alguna vez fue vencedor(a) y, no sólo eso, sino que convirtió al perdedor en una gallina. Le quitó su propia virilidad, su propio valor, pues lo tuvo "de rodillas, sin moral, hecho un mendigo/ cuando se fue”. Esa absoluta disolución de sí mismo es lo que se nos cuenta en lo que podíamos llamar el segundo acto del tango, en esa especie de flash-back en que se nos recuerda el pasado de hace diez años. Y el telón cae en el último acto: si el gallina que ha visto al gallo picoteado (a la chica descangayada), que se ha visto a sí mismo en ese espejo de miseria moral y física, se ha pasado todo el día autocastigándose, rajando y pensando, lo lógico es que el texto concluya como lo hace: "esta noche me emborracho bien/me mamo bien mamao/ pa no pensar".

De hecho hay una fatalidad, como una especie de destino implacable, que 
marca siempre los tangos de Discépolo. No es extraño así que a veces se comparara la atmósfera de esos tangos con la de la literatura nihilista rusa de fines del XIX, con los textos de Andreiev, por ejemplo. En Uno, esa obra clave de 1946, o sea, escrita cinco años antes de su muerte, hay alguien que lucha por creer aún en la vida aunque sabe que ya es imposible porque precisamente el "uno" ya no existe. Parece una historia de amor, de un amor que llega demasiado tarde. El amor quizá hubiera conseguido la reconciliación con uno mismo, la auto-identificación, pero la última parte del poema, (que casi nunca se canta, quizá porque sería demasiado largo) resulta espeluznante: "Déjame que llore como aquel/ que sufre en vida la tortura/ de llorar su propia muerte". Y tras dos versos de transición ( "Uno está tan solo en su dolor/ uno está tan solo en su penar”) llega a la conclusión inevitable. ¿Qué queda? Como escribe Discépolo, únicamente: "Un frío cruel/ más cruel que el odio/ punto muerto de las almas". Ese cero de la vida, ese punto muerto de las almas, es en verdad una increíble imagen gélida, el lugar ciego de todo, casi la plastificación viva de ese proceso a la individualidad que decimos que Discépolo establece a través de sus tangos.

En Yira, yira, muy anterior, de 1930, hay que tener en cuenta que el mundo no sólo "gira" con indiferencia abstracta sino que "yira" puede significar también prostituta. Y que cuando la suerte (o sea, el destino) que es "grela" ( o sea, que es mujer) te deja fuera de juego, el uno se convierte en un otario, o sea, en una especie de perro tonto, que un día se cansa y se pone a ladrar: "Verás que todo es mentira...etc." Creo que es un poco exagerada, quizá fuera del tono de Discépolo, la imagen final de que mientras te estás muriendo ya se prueban la ropa que vas a dejar. Pero la lucha contra esa indiferencia del mundo, "que es sordo y es mudo", se vuelve magistral en la imagen directa de: "Cuando estén secas las pilas/ de todos los timbres que vos apretás". Vivir es llamar a unos timbres que siempre están secos, encontrar todas las puertas cerradas. Sólo lo seco existe. El nihilismo de Discépolo vuelve aquí a hacerse patente y de manera directa. Incluso intenta ser aún más metafísico en Cambalache, de 1935. Sin duda es el más famoso, pero acaso no el mejor de los tangos de Discépolo, aunque la descripción de la locura de los años 20 (y del siglo XX) no deja de ser válida tanto en los nombres concretos o en las descripciones abstractas que él da, como en la saturada y auténtica conclusión final: "En un mismo lodo/ todos manoseaos". Evidentemente Discépolo no sabía descifrar bien la historia, pero lo que hemos llamado 
su existencialismo nihilista y vital resulta así indiscutible. Y quizá lo que importe sea precisamente un síntoma histórico: la ausencia de sentido de la vida de nuestro mundo, otra forma del vacío.

7.- Por supuesto que Discépolo también tiene tangos de directo contenido satírico, como Chorra, (o sea, ladrona), de 1928, donde se nos cuenta como a un pobre carnicero, una chica que se decía hija de la viuda de "un guerrero que murió lleno de honor", le roba todo, y además él se entera de que la viuda también es ladrona y de que el padre está en la cárcel por matón, malandrín y estafador. Todo está envuelto en el grotesco: al personaje le asustan luego tanto las "minas", o sea, las chicas, que si alguna se le acerca en la calle él se pone “al lao del botón”, o sea, del policía. De no menor fuerza satírica es Victoria, de 1930, donde el protagonista nos lanza su famoso “Cantemos victoria/ se fue mi mujer”, a la vez que siente pena por el pobre marino que se la llevó. Obviamente aquí el dolor del amor tanguero se ha transformado por completo. Como se transforma el "malevaje" en el tango del mismo título y de 1929. El típico malevo admirado por Borges y por todos los tangos, se transforma ahora de nuevo en la gallina dominada por el gallo, por la presencia apabullante de una mujer y por el miedo a perderla. Y otra vez con una clara imagen de la disolución de la individualidad: "estoy tan cambiao/ no sé más quién soy”. Tiene otras metáforas fantásticas: "No me has dejao ni el pucho (o sea, el cigarro) en la oreja" / de aquel pasao malevo y feroz". Y especialmente el final: "Ya no me falta pa completar/ más que ir a misa e hincarme a rezar" O sea, exactamente lo que haría un "gil llorón" en vez de un malevo auténtico. Malevaje es la mejor representación de lo grotesco que escribió Discépolo. Pero para terminar esta breve historia debo decir que de toda su obra yo me quedo, curiosamente, con el último gran tango que Discépolo escribió ya en 1948: Cafetín de Buenos Aires. Primero nos recuerda cómo desde chiquilín lo miraba desde afuera, con la nariz - la ñata- pegada al vidrio, al cristal, y luego todo lo que aprendió en él y finalmente un verso de resignación definitiva: "Bebi mis años/ y me entregué sin luchar". Ya no hay ganas de luchar contra el mundo o contra el destino y menos contra los desengaños amorosos (el machismo de Discépolo es tan obvio como el de toda la tradición tanguera). Pero veamos lo que aprendió en el café y anotemos cómo era ese mundo. Escribe Discépolo verso magistrales al respecto. Pero recordemos sobre todo estos: "En tu mezcla milagrosa/ de sabihondos y suicidas/ yo aprendí filosofia/ 
dados, timba.../ y la poesía cruel/ de no pensar más en mi’”. Y aquí está todo conjugado: esas son las otras islas que Discépolo solía mostrar en sus tangos, en su tono y en sus imágenes fulgurantes.

En el largo ensayo que escribí sobre el tango para el libro Granada tango ${ }^{9}$ dejaba constancia de la impresión que siempre me habían producido esos dos versos finales: "La poesía cruel/ de no pensar más en mi”. Esta es en efecto la nueva subjetividad que Discépolo introdujo en el tango ya desde muy pronto, pero que ahora se hace decididamente explícita. Ese es su tono, su distancia: hablar desde el yo para "no-pensar-más-en-mí". Eso es lo que revolucionó el tango, porque los letristas habituales, incluido Gardel, hablaban más bien de "No pensar más que en mì". Ahora descubrimos quizá el verdadero secreto de Discépolo, lo que venimos llamando su nueva mirada sobre la individuación: parece que hablo de mí, pero rajo o ladro precisamente para no pensar más en mí. También ahora quizás se comprenda mejor el por qué he venido hablando de que los tangos de Discépolo suponen de hecho un "proceso a la individualidad" sin dejar de ser tangos. Es decir, esa individualidad siempre tambaleante es precisamente el pensamiento triste que se baila.

¿Se suicidó Discépolo o se murió de un ataque de la tuberculosis que padecía? Nunca lo sabremos. Quizá nos lo hubieran podido decir su compañera de años, la cantante Tania (la española que, al parecer de tantos, tanto le amargó) o su amigo Homero Manzi. Pero éste sólo quiso dedicarle un tango en homenaje, precisamente el titulado Discepolín (cuando Manzi murió también se le dedicó un tango que decía: “Total al fin nada es cierto/ y estás hermano despierto/ juntito a Discepolín). Ni siquiera su hermano mayor, Armando, supo de qué había muerto Discépolo. Al preguntarle al médico: “¿De qué ha muerto mi hermano Enrique?”, el médico se limitó a contestar: "De ganas".

Se cuenta que tras perder a su padre con cinco años y tras perder a su madre con nueve, el niño Enrique Santos Discépolo, al que le habían regalado un globo terráqueo, lo cubrió con una tela negra. Quizá ese luto por el mundo era el que llevaba dentro y el que redescubrió finalmente al escribir el grado cero de la vida, la poesía cruel de "no pensar más en mí”.

\footnotetext{
${ }^{9}$ Op. Cit.
} 


\title{
B.- EL BOLERO Y LOS LÍMITES DEL DESEO
}

\author{
I \\ La falsa suavidad del bolero
}

1.-Si se me dice que los Boleros son cúrsiles tendría que decir que sí, pero entonces nos veríamos obligados a rastrear el sentido de lo cursi en el ámbito de la Cultura populista y melodramática de la literatura latinoamericana. Y a la vez dar un salto a lo kitsch y a la parodia o el pastiche en España, Europa y Estados Unidos y la lista de categorías sería interminable. Pues habría que incluir emblemas tales como lo urbano y lo rural, lo popular y lo pop, lo puro y lo impuro, lo alto y lo bajo, el cine, la radio y la televisión, el periodismo y los best-sellers, lo rockero y lo punk o lo freaky; y no digamos internet, los móviles, o los vídeos caseros. Y habría que incluir nombres propios: desde lo urbano de A. Ganivet ${ }^{10}$ a lo cursi de Gómez de la Serna; desde Baudelaire o Walter Benjamin a Karl Krauss y Hermann Broch; desde Gramsci a la autonomía operaia de Toni Negri; desde Raymond Willians y el primer Stuart Hall a Terry Eagleton; desde Bourdieu y Passeron a D. Ramón Menéndez Pidal, a Manuel Vázquez Montalbán o Iris Zavala. Y por supuesto desde Sarmiento y Borges a Mariátegui o Martí o Alejo Carpentier. Ni siquiera incluyendo a las feministas, los gays, la era del jazz de Scott Fitzgerad, o Las Vegas de Frank Sinatra y Elvis Presley, podríamos concluir la lista. O mejor dicho, las listas sólo se elaboran hoy en la infinitud de los Estudios Culturales y Estudios Poscoloniales que florecen como hongos en la Academia Norteamericana. El por qué de ese florecimiento de hongos sí que es complejo (o fácil) de analizar, pero no en este momento.

De modo que sólo me queda volver a Brecht y recordar que, como se sabe, Brecht decía que lo peor de su exilio escandinavo, con los nazis pisándole los talones, era que se le estaban acabando sus medios de producción: los cigarros y las novelas policiacas. Desde esa admirable distancia de supervivencia Brecht se estaba autoironizando a sí mismo y desde la distancia de hoy, apoyándonos ahí, para poner algún

\footnotetext{
${ }^{10}$ Cfr. J.C.R.: "El mito de la ciudad mujer de Ganivet a hoy" en De qué hablamos cuando hablamos de literatura, Op.Cit., pp. 117-154. Escribe Ganivet: "Madrid tuvo sus ensanches, y Barcelona el suyo, y Valencia y Bilbao..." Estaba obsesionado con los problemas de la línea recta en las nuevas "grandes vías" urbanas.
} 
sentido dialéctico frente al mundo esquemático de los Estudios culturales y poscoloniales yanquis, intentaré por mi parte anotar algunas cuestiones básicas sobre la lógica interna que sostiene la multiplicidad de sentidos del bolero y su feeling ${ }^{11}$.

2.- Comenzaré pues así: "Los ojos se le cerraban, no por cansancio, sino de tristeza, una tristeza de años. La sonrisa que esbozó para agradarme se perdía bajo el peso de aquellos ojos".

Esta tristeza de años, donde la sonrisa se traslada a los ojos de niebla, creo que es la mejor definición del bolero. He elegido la cita extrayéndola de una novela de un escritor negro como Walter Mosley ${ }^{12}$, porque quizá nos lleva al centro mismo del bolero, el titulado "Lágrimas negras". Pero junto a esa tristeza de años, de sonrisas o miradas, de días o siglos o vidas "entre paréntesis", existe otro lado del Bolero. Y si quisiera resumir todo el núcleo clave de ese otro lado del bolero no lo dudaría ni un instante. Sería este verso: Voy a perder la cabeza por tu amor.

El borde de la locura y el límite del deseo son, junto a la tristeza de fondo, los signos que marcan al bolero, por lo menos al "bolero estándar" que conocemos, el que se fijó entre mediados de los años 20 y los años 50. O más en estricto entre el final de la primera guerra mundial y sobre todo tras la posguerra de la segunda gran guerra, a partir de los años 50, que afectó mucho más directamente al Caribe y a México que al resto de América Latina. Si Cuba, México y Puerto Rico son (sin duda por este orden, incluida la República Domimicana) la cuna del bolero, en los programas de radio portorriqueños donde se emitía el bolero se hablaba de los muchachos que iban a morir por la patria (norteamericana), primero en la guerra de Corea y luego en la del Vietnam, una época, ésta de los años 70, donde quizá comienza la decadencia creativa del bolero. Naturalmente se trataba de una ambigüedad buscada: lo mismo que los británicos tuvieron su gran ejército de tierra (la R.A.F. o la Marina eran otra cosa) a partir de las tropas hindúes (por ejemplo aún hoy los “gurkas”), del mismo modo, digo, la infantería yanki, sobre todo los “marines", se nutrió de negros, portorriqueños, chicanos y blancos pobres (la aviación era otra cosa), Y esa gente "hispana" que dependía de los Usa, de un modo u otro, era la verdadera receptora, el verdadero público del bolero estándar al que

\footnotetext{
${ }^{11}$ Dedicaré estas líneas a mi amigo Guillermo Rodríguez Rivera, el profesor cubano que realmente se sabe todos los datos de esta historia.

${ }^{12}$ Walter Mosley, Betty, la negra, Anagrama, Barcelona, 1997.
} 
aludimos. Pues el bolero que conocemos siempre estuvo partido en dos: entre el Caribe y Nueva York. Evidentemente su fácil ritmo de 2x4 (con múltiples variaciones) se introdujo por toda la América latina y reabsorbió incluso temas característicos del Cono Sur, como el tango (El día que me quieras, de Gardel es ya más un bolero que un tango, aparte de su título tomado de Amado Nervo), el populismo chileno (que tuvo en Lucho Gatica a su gran representante bolerista, pero quizá también a alguien que trabajó con él acompañándolo al piano, el mejicano Armando Manzanero, el último gran creador de boleros), incluso a los valses peruanos de Chabuca Granda, como Fina estampa o La flor de la canela (que siempre se han solido cantar luego abolerados). Un trío mejicano como Los Panchos (los supuestos “admiradores" de Pancho Villa), con su juego de voces y la introducción de la guitarra pequeña llamada "requinto", constituye acaso el símbolo central de ese aboleramiento progresivo de toda la música y de todas las letras cantables latinoamericanas, hasta que el feeling (o "filin") del bolero comenzó a perderse para pasar a ser trepidante: desde el Cha, cha, cha o el Mambo de Pérez Prado a la Lambada de ayer mismo. No hay negocio como el negocio del espectáculo. Y la dulce suavidad del baile agarrado del bolero, mecido por el fraseo de sus letras o la dulzura de sus músicas, ya comenzaba a no ser negocio a partir del éxito del Rock and roll y los ritmos surgidos en su entorno. Claro que en los Usa existía la música Country y el Swing de Frank Sinatra (que también cantó boleros, como Nat King Cole, incluso el Begin to begin de Cole Porter es de hecho un bolero), y ese swing, digo, podía compaginarse perfectamente con la pelvis de Elvis Presley. Pero es que, obviamente, el mercado Usa es mucho mercado y el mercado latino apenas una especie de minucia al lado suyo. Incluso podíamos decir que el ritmo del bolero, que quizá era demasiado bronco en sus principios, luego, en los años 40 y 50 se suavizó más imitando el modelo feeling norteamericano. Puesto que los tiempos estaban cambiando y en los 60 y los 70 el mercado joven impuso el baile narcisista, el baile de cada cuerpo por su cuenta, y el bolero estaba pensado para bailarse por parejas. Posteriormente la "música tecno" o la "música disco" parecieron acabar con el bolero, pero sólo en parte. Si el rock comenzó siendo más barriobajero, no sólo en el King Creole de Elvis, sino sobre todo en su trasplante británico a los Beatles o a los Rolling, aparecieron a la vez otras músicas no tan rotas, pero sí ya separadas, con el ritmo sólo fijado en el propio cuerpo, como el Twist, un verbo que obviamente significa girar, pero que se semantiza subjetivamente 
como "twister", el girador descoyuntado, digámoslo así, "girando sobre sí mismo". Las grandes orquestas norteamericanas, la de Glen Miller por ejemplo, las jazz-band que intentaban popularizar el jazz suavizándolo, eran ya demasiado caras en los años 60, y el jazz como el tango, como el flamenco (si exceptuamos quizá a Camarón) o incluso la "Canción española" del franquismo que analizó M. Vázquez Montalbán (luego transformada en la "Copla andaluza"), todo ese amasijo de músicas se convirtió de hecho en un ghetto. Evidentemente, sin embargo, en el mundo anglosajón no desapareció el feeling o el swing: por ejemplo, con The Platers o con el nuevo relanzamiento de Sinatra al conseguir el Oscar por su papel en De aquí a la eternidad y al grabar el inolvidable May way, un inesperado tema francés ("Comme d'habitude") que le arregló el canadiense Paul Anka adaptándolo al “individualismo" norteamericano. Y, lógicamente, fue a esa pervivencia del feeling (el filin cubano) o del swing a la que se agarró desesperadamente el bolero para establecer su nueva fórmula estándar entre los años 40 y finales de los $60^{13}$. El bolero seguía siendo el verdadero canto al sentimentalismo amoroso en castellano y a la dulzona melodía de la pareja.

3.- Y aquí la sorpresa: lo más curioso del bolero es que siendo una canción de amor y un baile de parejas, "agarrado", sin embargo siempre habla del desgarro de la pareja y de la imposibilidad del amor. En otros tiempos solía decirse que el bolero merecía el premio a la natalidad que otorgaba el franquismo: es obviamente imposible calcular cuántos romances, sueños, noviazgos y matrimonios y niños se han hecho al compás del bolero. Pero fijémonos sólo en dos boleristas españoles: Carmelo Larrea, el bilbaíno que escribió, tras un turbulento escarceo amoroso con una sevillana, el famoso: "Están clavadas dos cruces/ en el monte del olvido/ por dos amores que han muerto/ sin haberse comprendido..." Esos dos amores que habían muerto eran naturalmente el "tuyo" y el "mío", pero parecía como si la realidad de la ausencia de amor aumentara la presión del amor. O bien el otro extremo, o sea, cuando la presión del amor se hacía demasiado fuerte en el bolero: así la cantante valenciana Lolita Garrido, cuya versión en disco y en público del Bésame mucho fue censurada por una procacidad que no tenía nada que ver con lo cotidiano que se le suponía a la norma de la pareja matrimonial. No

\footnotetext{
${ }^{13}$ Claro que en los años 60-70, el filin, el country, el rock, etc., también se utilizaron en la llamada canción rebelde o de protesta social, como en el caso de Bob Dylan, Pete Seeger o Joan Baez; Silvio Rodríguez o Pablo Milanés; Violeta Parra y Víctor Jara; y por supuesto los llamados "cantautores" con la agonía franquista en España. Aunque fue el tono "psicodélico" (sexo y drogas) el que acabó por imponer su lógica, dentro de la lógica del sistema.
} 
conozco apenas boleros que hablen de la felicidad de la pareja diaria y hay censados más de tres mil boleros en empresas oficiales de discos. Quizás alguno de Armando Manzanero hable de la pervivencia del amor diario y conjunto, en letras como: "Te doy las gracias por hacerme tan feliz" o acaso también Somos novios. Hay otros ambiguos en este sentido, y por poner un ejemplo elijo el "cursi" Rayito de luna: "tú diste luz al sendero/ en mi noche sin fortuna/ iluminando mi cielo/ como un rayito claro de luna"; pero no nos hablan más que de instantes de iluminación, como el María bonita de Agustín Lara, donde aparecen algunos de los versos sensuales que más me gustan: no sólo el cuerpo de ella como juguete del mar mientras enjuaga las estrellas con sus manos sino la complicidad de la luna que se hace "un poquito desentendida" y que al esconderse empuja al abrazo de los cuerpos. Un tipo de iluminaciones que se encuentran de un modo u otro en algunos boleros tan decisivos como Recuérdame, Júrame o "Se me olvidó que te dejél lejos muy lejos de mi vida./ Se me olvidó que te olvidél y así volvió a sangrar la herida..." para terminar con el famoso dístico "Se me olvidó que te olvidél a mí que nada se me olvida".

Se trata, pues, de iluminaciones, ráfagas, instantes que en general tratan de volver a aprehenderse inútilmente en el momento en que se nos cantan, como si la letra y la música hicieran un juego mágico imposible: volver a revivir el instante es lo que permite que el bolero sea un instante, un "claro" del amor mientras dura la canción y el amor. Ese revivir el instante, ese hacer presente la iluminación que sucedió, es lo que sostiene, de hecho, lo que de otro modo sería imposible. Lo que sostiene eso que acabamos de llamar la sorpresa del bolero: si cuando parece hablar de la dulzura del amor y de la pareja, lo que el bolero nos cuenta es la imposibilidad del amor y de la pareja, tal magia se hace posible precisamente a través del instante, de la iluminación, de lo que dura el texto y nada más. Así, al filo del instante revivido, es como se fragua todo el valor del bolero, un valor que es sólo el momento de la pasión, y luego vienen el adiós, la ausencia, el recuerdo, el engaño, el reproche, el perdón... una Enciclopedia, en suma, con miles de letras y músicas sobre el amor, pero sólo sobre el amor como ruptura inevitable. Ilumínate, parece decirnos el bolero, porque esa iluminación sólo te va a durar mientras el bolero te atrape, mientras el bolero dure. El resto serán Cenizas sin sentido- o Sombras nada más, por citar títulos de otros dos boleros inolvidables. 


\section{El bolero tiene letra inconsciente (o de dónde son los cantantes)}

1.- Evidentemente el bolero no tiene nada que ver con el baile español que se llamó así en el siglo XVIII. En realidad en Cuba, la verdadera cuna del bolero, existía ya desde mitad del XIX al menos, una tradición folklórica cuyo centro más significativo suele situarse en Santiago, pero que de hecho flotaba por toda la isla y acababa focalizándose en La Habana. De la tradición de la danza, de la habanera, de la contradanza, etc. fue surgiendo el humus de lo que hoy se llama la "Vieja Trova". Junto al sastre mulato y conspirador José "Pepe" Sánchez o el autodidacta y también luchador independentista Sindo Garay (digamos, los dos nombres básicos de la época de la independencia), aparecen otros nombres claves como Manuel Corona, Alberto Villalón, Rosendo Ruiz, Patricio Ballagas, Graciano Gómez o Companioni, ciego desde los once años y autor del mítico bolero cubano Mujer perjura. Obviamente a estos primeros troveros o trovadores, (bardos o autores de la canción cubana en general), se les hacían contratos leoninos para sus actuaciones en público; ellos malvendían sus canciones y muchos acabaron en la miseria, incluso pidiendo limosna desde el periódico como Manuel Corona. Y ello tanto si tocaban en sus lugares habituales, en las plazas o en la calles y en teatros de mala muerte, como cuando tocaban en los sitios ricos al más puro estilo gringo, como el "Vedado Tennis Club", el "Country Club" o el "Casino Nacional". En esta "Vieja Trova" se fermentó el bolero y en los años 20 el Son. Quizás el primer bolero que se constata como tal sea Tristezas, de Pepe Sánchez, un bolero del que existe incluso una versión en México en 1910, mucho antes de que en México se pensara en el bolero. La abolición de la esclavitud y la independencia bajo control norteamericano dieron a los cubanos una necesidad de búsqueda de señas de identidad autóctonas; y sin duda eso hizo que comenzaran a adquirir "carta cultural" ciertos temas populares, desde la Santería a la Trova, y con ellos el bolero. Podemos elegir tres pequeñas muestras de este humus musical y de la importancia de sus letras. En una canción de Sindo Garay, El beso, está concentrado ya todo el despliegue posterior del bolero. Hablando de las lágrimas de ella, dice Garay: "Arroyo que al mojar las comisuras/ de mis labios dejó una huella clara,/ dejó miel en mi boca como para/ endulzar todo el mar de mi amargura". Confieso que siempre me ha llamado la atención el encabalgamiento de estos versos. No es fácil dejar suelto un término tan 
cultista como "comisuras" para luego encadenarlo con "de mis labios" y, por supuesto, no es fácil dejar suelta la preposición "para" y ligarla luego con "endulzar" e incluso hacerla rimar con "clara". Sindo Garay, el trabajador tabaquero que tuvo que dejar el trabajo porque terminaba de cantar con los demás troveros a las tres o las cuatro de la madrugada y estaba demasiado cansado para ir a la fábrica, nos dirá luego: "Yo no nací poeta. Yo nací con la vocación de músico. Pero la rima y el sonido que "habla sin palabras" me hizo ir al idioma castellano, que es el único que poseo". "Hablar sin palabras" es una imagen espléndida. Pero fijémonos en que evidentemente el castellano poético de la época era una mezcla de romanticismo almibarado y de modernismo de palabras raras: "comisuras" debió parecerle a Sindo una de esas palabras raras (y por eso quizás la dejó sola y flotando); y el sentimentalismo romántico está claro en esa imagen de la miel que endulza todo el mar de la amargura. Esa miel que luego se derramará en los boleros como frambuesa, empapándolos, aunque a veces haya un contracanto (por decirlo en términos del Son) mucho más seco, más satírico o cínico, como si el Compay Primero (o sea, la primera voz) cantara una cosa y el Compay Segundo la contracantara a la inversa. Así podemos verlo en dos textos de Graciano Gómez. El titulado Es sinceridad, donde el desgarro del bolero, la ausencia del amor, o mejor, la mentira del amor se contrapone a la sinceridad del odio: "porque tu cariño era todo falso/ y tu odio siquiera es sincero". Esa sinceridad es la que se agradece en la canción, y como se trata del "odio" se nos muestra que el bolero también puede ser duro. Y sin duda cínico y hasta con ribetes que hoy llamaríamos casi surrealistas, como en la magnífica metáfora de los dos versos claves de la canción Prodigio, del mismo Graciano Gómez: "Me arranqué el corazón cuando te fuiste/y mira qué prodigio: seguí andando".

Pero el origen humilde del bolero continuó pesando demasiado sobre él, hasta que acaso Alberto Villalón abrió una brecha, ya en 1906, al presentar el espectáculo "El triunfo del bolero" en el Teatro Alhambra de La Habana; y quizá con la aparición de Eusebio Delfín, que trabajaba como ejecutivo de un banco y que se casó nada menos que con una hija de Emilio Bacardí, el dueño de la famosa empresa de ron. El propio Eusebio Delfín cuenta con sorna que cuando un empresario fue a contratarlo, con el miserable contrato de costumbre para los demás cantantes, nada más ver el despacho y la ropa de Delfín rompió de pronto el contrato y allí mismo redactó otro de mucho más 
empaque. No cabe duda de que la presencia de Delfín entre la alta sociedad habanera hizo que esta empezara a mirar el bolero de otro modo, al menos con un mayor respeto. La situación -o la Distinción- de clases, de que habló Bourdieu con indudable agudeza está siempre latiendo por todas partes.

Pero evidentemente el auge del bolero y del son se debe a la aparición, ya en los años 20, de dos nombres míticos: el Trío Matamoros y María Teresa Vera. Miguel Matamoros es el autor de ese casi himno cubano, el aludido bolero Lágrimas negras ("Aunque tú me has dejado en el abandono/ aunque tú has muerto todas mis ilusiones..."), con un curioso -y posteriormente añadido- quiebro final de son ( “Contigo me voy mi santa/ aunque me cueste morir"); una santa que nos remite al son El paralítico, quién gracias a la santería puede tirar las muletas y bailar el son y que alberga toda la vitalidad cubana.

3.- Una historia que merece ser contada un poco más en largo. Digamos así que, de hecho, para conocer la historia fabulosa de la música y la canción popular en todos los ámbitos caribeños, resulta inevitable partir del ya clásico estudio que llevó a cabo Alejo Carpentier y que tituló La música en Cuba (1946) ${ }^{14}$. Desde el siglo XVI hasta 1944 Carpentier nos cuenta tan sabrosa y magníficamente esa historia que uno se queda deslumbrado (el que a veces haya planteamientos esquemáticos es lo de menos). Para dar alguna muestra del tono del libro bastará con remitirnos al año $1789^{15}$. En esa época el cronista Buenaventura Ferrer nos señala que el baile público se ha desbordado en La Habana: cotidianamente más de cincuenta bailes públicos que duraban toda la noche, algo que "casi toca la locura". Tanto que a la tercera contradanza, entre las bebidas y la música, "los bayladores habían dexado a un lado todo juicio y cordura". Como los bailes eran "de puertas abiertas" se mezclaban todos y todas: blancos, negros, criollos y criollas, mulatos y mulatas de cualquier tipo. Carpentier anota que "las mulatas, por su ángel y sabrosura, eran las reinas de estos bailes populares”, en los que triunfaban letras "de tono subido", como la espléndida "guaracha" Guabina, insustituible, que decía así:

\footnotetext{
${ }^{14}$ Manejo la edición del Círculo de Lectores, Barcelona, 2002.

${ }^{15} \mathrm{El}$ año de la toma de la Bastilla en la Francia revolucionaria y el de la umbría sequedad contrarreformista del incipiente liberalismo peninsular. El contraste entre la "alegría vital" de la isla caribeña y la negrura de Barcelona, Bilbao, Madrid o Sevilla (los pueblos sin vida de que hablaba Jovellanos pocos años antes) resulta escalofriante, sin duda.
} 


\author{
"La mulata Celestina \\ le ha cogido miedo al mar \\ porque una vez fue a nadar \\ y le mordió una guabina. \\ Dice doña Severina \\ que le gusta el mazapán, \\ pero más el catalán \\ cuando canta la guabina. \\ Entra, guabina, entra, \\ por la puerta de la cocina".
}

Y que cada uno/a interprete la guaracha "de tono subido" obviamente como quiera. Pero en las páginas 117-20 de la última edición citada del libro de Carpentier se pueden hallar detalles perspicaces al respecto (junto a la "anotación musical de la propia “guaracha”). Y, entre esos “detalles perspicaces”, recuerda Carpentier las imágenes que se han convertido ya en definitivas: "Las mulatas", compitiendo con las negras y con "los hombres que sudaban" o los jóvenes criollos que lógicamente, en esos bailes, no hacían distinción de color o de clase (a Carpentier, lógicamente también, se le olvida decirnos si las jóvenes criollas podían hacer lo mismo). Evidentemente no (en público, "a escondidas" era otra cosa), pero parece claro que la intención de Carpentier es mostrarnos el continuo balanceo entre la música popular afrocubana (el son, la rumba, el bolero) y su trasvase permanente (y sobre todo final) a la música digamos "clásica", con nombres tan significativos como Amadeo Roldán y Alejandro García Caturla. Que la música "alta" de Roldán y Caturla se inspira en el sustrato cultural del mestizaje caribeño, resulta indudable (e incluso también se dan trasvases de lo "alto" a lo popular, sólo que esto no tiene nada de extraño).

4.- Ahora bien: si la Guabina del XVIII (como luego la musicalización del poema de Martí Guantanamera, o La Paloma o La Golondrina) se ha convertido en señas de identidad cubana por excelencia, lo mismo podríamos decir del otro "himno" popular básico (junto a El manisero), o sea, el que Matamoros tituló "Son de la loma", pero que se conoce más por su segundo verso: "De dónde son los cantantes". La letra de Miguel Matamoros dice así:”Mamá, yo quiero saber/ de dónde son los cantantes/ que 
los veo tan galantes ${ }^{16} /$ que los quiero conocer./ Son de la loma,/ y cantan en llano,/ tú verás, vamos a ver,/ mamá, ellos son de la loma,/ mamá, ellos cantan en llano (bis)...”

Parecerá quizá excesivo que se reproduzca aquí la letra de la canción más caribeña (Lágrimas negras también lo es, pero con un matiz digamos mucho más subjetivo), la canción cubana por excelencia. Pero lo hago para anotar simplemente un par de cuestiones: $1^{\circ}$ ) no hay porqué buscarle mucha trascendencia mística o esotérica a esta canción. Por ejemplo, que la Loma o los montes signifiquen un lugar sagrado africano, o algo así. Ni darle tampoco mayor importancia al hecho (obvio) de que la relación "hija/madre" provenga de la tradición hispánica medieval. En efecto, ese entronque "tradicional" de la imagen de la chica "que quiere saber" y pregunta a su madre, implica una imagen del "saber/no saber" sexual femenino (como si la hija lo supiera "ya-todo" aunque no supiera "por qué" y la madre fuera su única confidente), una enunciación "literaria/ tradicional" repito, que en efecto ha perdurado durante siglos. Como signo de la condición de la mujer y como signo del "cultismo" (más o menos ingenuo) que siempre late en la canción popular, como indicábamos. Y $2^{\circ}$ ) lo más evidente: Matamoros escribe en una coyuntura histórica concreta en la que Cuba era básicamente La Habana, mientras que Oriente (o la ciudad de Santiago) era una zona provinciana y "palurda”. Lo que Matamoros nos indica pues, sencillamente, es el hecho de que su presencia en La Habana (en el llano) deslumbra aunque sean de Oriente (la Loma, la zona más montañosa y palurda de Cuba). Y deslumbran aunque ellos canten "en llano", o sea, cantan con voz y música campesinas, aparentemente "palurdas" y no sofisticadas en efecto. La anfibología del título corrobora esto: Son de la loma implica a la vez un verbo (los cantantes "son" de Oriente, "tierra soberana") y a la vez un sustantivo: lo que ellos cantan -lo que deslumbra- es un son, la música afrocriolla que mejor definiría la "cubanidad". No hay, insisto, más misterios que esa contraposición monte perdido/ ciudad esplendorosa. Y ese modo -magnífico- de reivindicar el son y sus cantantes que atraen a las jóvenes de La Habana: aunque canten “en llano" y en "el llano".

Por lo demás baste ya sólo con añadir que el "Trío Matamoros" tuvo diversos nombres y con ellos actuó en una gira por México Benny Moré, el otro gran clásico que

\footnotetext{
${ }^{16}$ En otras versiones se lee "elegantes", con lo que sobraría una sílaba, luego absorbida por el ritmo musical, como es lógico.
} 
se lanzó a la fama desde entonces. Pero en realidad fue la industria cultural norteamericana la que convirtió en famosos al trío y al bolero. Los tres primeros nombres (Siro Rodríguez, Rafael Cueto y Miguel Matamoros), los tres de Santiago, grabaron su primer disco en Nueva York en 1928, y del bolero Olvido vendieron sesenta y cuatro mil copias en tres meses. Eso era mucho vender y eso era la puesta de largo del bolero. Los discos y la radio formaban, junto a Broadway, Hollywood y la aparición de la publicidad, la clave del mecanismo de lo que Adorno llamó "industria de la cultura", de la verdadera difusión cultural masiva en Norteamérica. Y Nueva York sirvió como lanzadera del bolero, en especial para todo el público latino. De cualquier modo el bolero se internacionalizó, y aunque la música latina en Hollywood tuvo siempre una presencia un tanto grotesca (con Xavier Cugat y su perrita y sus rubias esplendorosas, o los sombreros de frutas de Carmen Miranda), no podemos olvidarnos de que en una de las escenas clave de Casablanca, Bogart e Ingrid Bergman bailan solos en el bar precisamente un bolero, nada menos que Perfidia. El otro nombre básico al que aludimos es, sin duda, María Teresa Vera, a la que se le llamó el símbolo de toda Cuba y a la que Silvio Rodríguez y Pablo Milanés han dedicado siempre una gran admiración y el reconocimiento de su influencia en la "Nueva Trova". María Teresa era hija de un militar español que murió en el barco que lo llevaba desde la península para conocer a su hija. Así que sólo vivió con su madre y adoptó el apellido Vera -como solía ser normal- de los amos que liberaron a su madre como esclava. Cantó sobre todo a Corona (Longina, Rosa Negra, Mercedes) y por supuesto otro casi himno popular de la canción cubana: Santa Cecilia. Se consagró en La Habana pero sobre todo en Nueva York, como era obligado, donde se vendieron veinticinco mil copias de su versión de la Mujer perjura, de Companioni, aunque ella hizo la grabación gratis y no se llevó ni un dólar. Actuó con diversos acompañantes y grupos y su vida personal fue azarosa y agria, hasta que se encerró en la santería y estuvo tres años sin cantar, según las reglas santeras. Reapareció con Lorenzo Hierrezuelo, que la acompañó casi 30 años. Sintomáticamente el bolero titulado Veinte años sería hoy quizá el más conocido de María Teresa Vera: "¿Qué te importa que te ame/ si tú no me quieres ya?/ El amor que ya ha pasado/ no se debe recordar./ Fui la ilusión de tu vida/ un día lejano ya,/ hoy represento el pasado/ no me puedo conformar./ Si las cosas que uno quiere/ se pudieran alcanzar,/ tú me querrías lo mismo/ que veinte años atrás..." etc. Un bolero, como vemos, donde lo que se canta 
es precisamente "lo que se pierde", donde lo que importa -como siempre- es el "desgarro", no la realidad del amor. No es seguro, al parecer, que sin embargo María Teresa Vera fuese la autora de la letra de todas sus canciones (imposible en una carrera tan larga: la letra de Veinte años es de Guillermina Aramburu, según todos los indicios ${ }^{17}$ ), aunque casi siempre fuera ella la autora de la música.

5.- Con la revolución castrista María Teresa se convirtió en un ídolo de esas "señas de identidad" cubanas que decíamos, (ya buscadas por Martí desde antes de la independencia), que se rastrean en los trabajos de Fernando Ortiz o de Miguel Barnet, e incluso en el título Orígenes, la revista de Lezama Lima, y que el populismo de los barbudos trató de intensificar al máximo. Barberito Díaz tocó en el funeral de María Teresa el bolero que acabamos de transcribir, Veinte años, la canción favorita de la mulata, una tradición trovera y un funeral al que no pudo asistir, ya muy enfermo, Lorenzo Hierrezuelo, que sin embargo sí dijo aquello de que María Teresa era "toda Cuba". Otro nombre mítico es, sin duda, Ernesto Lecuona, quizá el mejor músico que haya dado Cuba, y cuyas composiciones "serias" se han interpretado en todo el mundo. Pero Lecuona pertenece ya a otro ámbito, digamos el de la "alta cultura", y aunque compuso muchos boleros pasará a esta historia sobre todo por Siboney. Igual que otro gran compositor, Gonzalo Roig, pasará por Quiéreme mucho, con letra de Agustín Rodríguez y Ramón Gollury -una curiosa historia-, aunque Roig será siempre en Cuba el autor de la zarzuela más típicamente melodramática: Cecilia Valdés. Por su parte Lecuona tuvo un enorme éxito en la Península y murió en Canarias. Pero sus boleros son curiosos como síntomas: cuanto más complicada y con mejores arreglos era su música de bolero, más cúrsiles eran sus letras, más empalagosas dentro de lo que Federico de Onís llamó el "posmodernismo" en el ámbito hispánico, unos textos que pretendían ser no menos cultos que la música, y con ello las letras se deshilachaban. Diríamos que era un exceso en la perfección de la Norma, lo que el propio Federico de Onís hubiera llamado no un ultramodernismo, un paso hacia delante, sino un citramodernismo, un paso hacia atrás, hacia el primer modernismo aún romántico y sensiblero. Ese es el riesgo que se corre siempre que se intenta hacer "trascendentalmente poéticas" las letras de raigambre tradicional. Un hecho apreciable no sólo entre los músicos más cultos sino también entre los trovadores iniciales. Estos

${ }^{17}$ Cfr. Margarita Mateo Palmer: Del bardo que te canta, Letras Cubanas, La Habana, 1988. 
oían en los primeros gramófonos no sólo las óperas italianas sino incluso a Wagner (Sindo Garay se quedó tan impresionado que compuso una canción en homenaje a Wagner: Germania), pero esa poética cultista casi siempre salía mal. Es obvio que el bolero está lleno de connotaciones cursiles, lo cursi -decíamos- es una de sus claves. Y con este lastre se arrastró hasta México, donde incluso otros autores se arriesgaron más en este sentido de hacer "cultista" al bolero. En ese doble filo de la navaja apareció en México Agustín Lara que con doce años ya trabajaba como pianista en un burdel, hasta que se enteró su padre y entonces el joven Agustín se escapó para enrolarse con Pancho Villa. Lo llamó la revolución (aunque esto quizá forma parte sólo de su leyenda), pero su mala condición física (se mostraba en su delgadez asombrosa) pudo más que su no menos asombrosa vitalidad. Tuvo que dejar las filas villistas (si es que alguna vez estuvo luchando: algo así como Lope de Vega en la Armada Invencible) y empezó a tocar el piano, ahora en cabarets y salas de fiesta. Su formación musical se la consiguió él mismo, y su Madrid, Valencia, o Granada se asegura que las compuso sin conocer España, sólo por sus contactos con los emigrantes españoles, en especial con uno con el que compartía habitación en un hospital (desde hace años se afirma que sus letras “españolas" son en realidad de Rodolfo Chamaco Sandoval). Desde luego sí que compartió su vida con muchas mujeres, tanto que una de ellas intentó acuchillarlo por celos mientras tocaba en un cabaret y le dejó aquella cicatriz que le atravesaba la cara y que él lucía en el perfil de sus fotografías. La profesora Aurora de Albornoz escribió un precioso artículo sobre Agustín Lara, un artículo desgraciadamente hoy casi desaparecido. Pero la culminación turbulenta de Agustín Lara con las mujeres llegó con la borrasca llamada María Félix, que se atrevía a todo, incluso a cantar boleros. Una unión (lógicamente, también publicitaria) entre mitos, que se vivió y se acabó como en el vórtice de un huracán. Fue un cantante de boleros, Juan Arvizu, al que Lara acompañaba al piano, quien lanzó al músico Lara por el mundo del bolero, hasta que llegó a tener su propio programa de radio y todo el mundo lo imitaba, sobre todo María Grever (su apellido era De la Portilla; Grever era el apellido de un marido norteamericano). María Grever, como Consuelo Velásquez (su Bésame mucho es único), como Isolina Carrillo, me hacen pensar hoy que las mujeres escribían mejores boleros que los hombres. Quizás por ser consideradas siempre como "caramelos" lejanos en los boleros, ellas resultaron ser mucho menos acarameladas. Lo veremos 
enseguida. Digamos ahora sólo que durante un tiempo Lara se asoció con otro cantante mejicano decisivo, Pedro Vargas, que arrastraba las huellas populares de los corridos revolucionarios y de las rancheras, y que le daba un tono especial al bolero mexicano (como se puede apreciar también en Pedro Infante), intentando desmarcarse, sin embargo, del supuesto rancherismo puro de otro mito como Jorge Negrete (famoso en España por sus películas y su "Ay Jalisco no te rajes" o "La feria de las flores": "y traigo pistola al cinto/ y con ella doy consejos"), con el que sin duda competía Vargas, por ejemplo en "Pero sigo siendo el rey". Agustín Lara y Pedro Vargas significarían el dúo básico del bolero mexicano, si en los años 50 no hubiera aparecido José Alfredo (Jiménez, aunque para los mexicanos el apellido es lo que no existe. Curiosamente en España se cantaban sus canciones, pero el personaje "José Alfredo" resultaba prácticamente desconocido). El brillante ensayista Carlos Monsiváis hizo un espléndido análisis del "mito" de José Alfredo en su ensayo: José Alfredo Jiménez: "Les diré que llegué de un mundo raro”, desde 1950 hasta 1970: desde Yo (“Ando borracho, ando tomando/ porque el destino cambió mi suerte"), hasta El jinete: "Por la lejana montaña/ va cabalgando un jinete", Un mundo raro ("Les diré que llegué de un mundo raro"); o Amanecí en tus brazos (“Amanecí otra vez/ entre tus brazos”). Aunque para Monsiváis el verso más sintomático de José Alfredo Jiménez sea: "Yo sé bien que estoy afuera", algo que lo convertiría siempre en el poeta “de la desolación”, asumida y objetivada. Puede entenderse así, sin duda.

6.- Claro que también había aparecido antes la voz única de Toña la Negra. Toña cantó todo el repertorio de Lara desde 1932, aparte del Lamento Jarocho que Lara escribió especialmente para ella; y quizá fuera la mejor intérprete de Solamente una vez o Piensa en mí, para mí el otro gran bolero de Lara junto a María bonita. Tengo sin embargo una duda imposible de resolver. El primer verso de Solamente aparece de dos maneras en los Cancioneros y en las grabaciones: "Solamente una vez/ amé en la vida", que es como generalmente se canta, o bien "Solamente una vez/ amé la vida", que me parece mucho más inesperado y seco. Arráncame la vida, Noche de ronda o Señora tentación son otros tres magníficos boleros de Lara, con fraseos distintos en Vargas o en la Toña. Y aunque la Negra también tuvo poca difusión en nuestro país, su versión de Angelitos negros la retomó Antonio Machín y constituyó quizás el verdadero enraizamiento de Machín en España. Ese Machín, hijo de una cubana negra y un padre 
gallego o catalán, que supondría más de treinta años de éxito del bolero en España, un auténtico símbolo. La letra de Angelitos negros era de un poeta venezolano, asimismo "posmodernista" y de gran prestigio en su país, Andrés Eloy Blanco. De Isolina Carrillo es el otro gran éxito de Machín, Dos gardenias (otro mito también en Cuba), mientras que de María Grever son Cuando vuelva a tu lado, Alma mía ("Si yo encontrara un alma/ como la mía". Claro que ese alma también besa) o Júrame. De Puerto Rico surgen Myrta Silva, autora de "Qué sabes tú/ si tú no sabes nada de la vida"; Ruth Hernández, y quizá el compositor básico portorriqueño, Rafael Hernández (autor del famosamente "cursi" Capullito de alhelí). Entre los cantantes portorriqueños están los hermanos Rodríguez y sobre todo Daniel Santos (que también actuó en la orquesta de Xavier Cugat) y que ha merecido una novela dedicada a él: La importancia de llamarse Daniel Santos, (del magnífico novelista también portorriqueño Luis Rafael Sánchez, una verdadera narración/ reportaje sobre la difusión del bolero en todos los países latinoamericanos).

7.- Pero las mujeres y el bolero seguían imponiéndose, y de nuevo a partir de Cuba: Celia Cruz aparece con el conjunto La Sonora matancera (o sea, de la provincia de Matanzas); y un músico que no sabía música, Oswaldo Farrés, escribe temas tan magníficos como Toda una vida, Acércate más, Madrecita o Quizás, quizás. Madrecita fue un tema básico del fabuloso "Bola de Nieve" (¡esa increíble mano izquierda de su piano! $!^{18}$ ) y también por supuesto de Machín. Pero no podemos olvidar a Pedro Junco jr., el autor de Nosotros, a César Portillo de la Luz (Contigo en la distancia) y a Bobby Collazo, alguno de cuyos temas, como Vivir de los recuerdos, fueron básicos en el repertorio de otro mito femenino cubano, Olga Guillot. Más mujeres: la propia Olga Guillot e Isolina Carrillo formaron parte del grupo Siboney, Ana María González le estrenó a Lara Solamente una vez y el inevitable Madrid, sin olvidarnos de la argentina Libertad Lamarque, también tanguera pero que frasea maravillosamente el " $Y$ qué hiciste del amor que me juraste..." (del dominicano Mario de Jesús). Y, por supuesto de la peruana Chabuca Granda, cuya mejor intérprete ha sido María Dolores Pradera, en temas tan clásicos y ya aludidos como No se estila, Fina estampa, La flor de la canela,

\footnotetext{
${ }^{18}$ Sobre Bola de Nieve (Ignacio Jacinto Villa Fernández) habría que escribir mucho más. Baste ahora con remitirme al libro de Leonardo Depestre: Cuatro músicos de una villa, ed. Letras Cubanas, 1990. La villa es Guanabacoa, y allí nacieron Bola de Nieve, Lecuona, Juan Arrona y Rita Montaner, la inolvidable voz sensual de "Ay, mamá Inés".
} 
etc. María Dolores Pradera ha cantado siempre estos temas, como apuntábamos, en tono abolerado, y tras la herencia de Jorge Sepúlveda o de Bonet de San Pedro, es sin duda la voz por excelencia del bolero en España, que tiene otros representantes como los surgidos de la rumba catalana, (donde se integró el nombre de Moncho, el llamado gitano del bolero, y su versión de "Llévatela", de Manzanero).

8.- Pero volviendo a las mujeres tampoco puede dudarse de que el desgarro total del bolero se inscribe en la voz única de Chavela Vargas, incluso después de su larga temporada en el infierno del alcohol y las drogas. No hace falta recordar aquí su versión musical de Macorina (del hispano-cubano Alfonso Camín). Y en torno a ella podríamos establecer una especie de cesura, una especie de quiebro en el son abolerado: por una parte el feeling y por otra parte el bolero roto. A finales de los cincuenta, y para evitar lo que parecía ser una baja en la producción y distribución del bolero, una serie de autores e intérpretes como Olga Guillot, como Lucho Gatica, como Frank Domínguez (el autor de Mundo raro, de una ambigüedad sexual sorprendente para la época. El muy sabio y muy inteligente amigo José Olivio Jiménez, desgraciadamente ya fallecido, contaba a veces la génesis del Mundo raro con la precisión del mejor Oscar Wilde), decidieron imitar aún mucho más el fraseo-feeling de las canciones norteamericanas, como ya esbozábamos. Y desde esa plataforma surgió el mexicano Manzanero, quizá el último gran creador de boleros, desde que en 1958 Gatica le grabó Voy a apagar la luz para pensar en ti. Desde entonces, y hasta 1966, Manzanero hizo lo mejor de su obra: Adoro, Contigo aprendí, Somos novios, Cuando estoy contigo y sobre todo ese texto espléndido que para Gil de Biedma era el bolero por excelencia: Esta tarde vi llover. Pero por otro lado surge un nuevo estilo, el del bolero roto, el de bolero como contracanto del bolero. Y sus representantes son, sin duda, otra mujer, La Lupe y un autor clave, Catalino "Tite" Curet Alonso. La Lupe, de nuevo una vida agria y adversa, se llamaba en realidad Guadalupe Victoria Yoli Raimond, y le interpretó a Tite algunos textos tan básicos como La Tirana ("Según tu punto de vista/ yo soy la mala..."), Carcajada final o ese contracanto total del bolero que es Puro teatro ("Igual que en un escenario/ finges tu dolor barato...”). Esta extraordinaria letra de venganza y de distancia nos lleva directamente al problema del bolero como poesía. Pero de eso ya hemos hablado antes y recomiendo el trabajo del profesor Guillermo Rodríguez Rivera 
titulado Poesía y canción en $\mathrm{Cuba}^{19}$. Por mi parte me quedo con algunos versos sueltos. Por ejemplo estos de Marta Valdés: "Hoy estoy pensando que tal vez existas/ hoy está de fiesta la imaginación"; e incluso podría trasladarme desde el primitivo Eusebio Delfín con su texto Ansia o La doble inconsciencia de Manuel Corona (donde se regatea el precio del amor), hasta el inolvidable Usted, de Zorrilla y Gabriel Ruiz: "Usted es el culpable" -o la culpable, porque eso depende de quién lo cante-.

Claro que no podemos olvidarnos de algunos otros boleros clásicos como Somos del argentino Mario Clavell; la versión de En un rincón del alma, de Alberto Cortéz; Sabor a mí, del mexicano Álvaro Carrillo; Obsesión del portorriqueño Pedro Flores ("Yo estoy obsesionado contigo"); Ansiedad, del venezolano Jorge Enrique Saravia; Historia de un amor, del panameño Carlos Almarán; Envidia ("y cuando digo tu nombre/ tengo envidia de mi voz") del español Alfredo García Segura, arraigado en Chile; y por supuesto, Regálame esta noche, Reloj y La barca, tres temas de Roberto Cantoral que fueron claves para Lucho Gatica; o el inevitable Alma, corazón y vida del peruano Adrián Flores Alemán. Por supuesto hay miles de boleros más, pero para terminar me gustaría recordar simplemente -o de nuevo- un bolero de "quiebro", de auto-sarcasmo pleno, como el magnífico Total del cubano Ricardo García Perdomo: "Total/ cuanto tiempo perdido.../ Total/ si no tengo tus besos/ no me muero por eso,/ que ya estoy cansado/ de tanto besar".

¿O quizá un hartazgo de frambuesa? El mexicano Luis Demetrio trató de limpiar esas manchas de mermelada con una inversión del planteamiento: la dureza o desgarro más brutal, casi siempre puesto en boca de una mujer: "Voy a mojarme los labios con agua bendita/ para lavar los besos que un día me diera/ tu boca maldita./ Voy a ponerme en los ojos/ un hierro candente/ pues mil veces prefiero estar ciega/ que volver a verte"; o bien en Bravo: "Te odio tanto/ que yo misma me espanto/ de mi forma de odiar". Y por supuesto la Copa de vino: "Alcé mi copa de vino/ para brindar por tu muerte,/ porque es la única forma/ que puede mi alma dejar de quererte...”.

Ciertamente ese brindis no está mal para un bolero.

\footnotetext{
${ }^{19}$ Ahora ampliado el texto en su Literatura y poesía en la trova cubana, La Jiribilla, La Habana, 2002. Igualmente de Gabriel Zaid: Ómnibus de la poesía mexicana, Siglo XXI, México, 1999; y Darío Jaramillo Agudelo: Poesía en la canción popular latinoamericana, Pre-Textos, Valencia, 2008.
} 
III

Final

Entre el bolero y el tango, o cuando los cuerpos hablan

1.- Nos encontramos así, finalmente, con los problemas de la textualidad del bolero: lo cursi, el melodrama, el Nosotros. Creo que todo el problema del bolero radica en el Nosotros. Puesto que el Nosotros es dual: por una parte el tú y el yo, eso está claro; pero por otra parte el nosotros somos todos. Y ¿quién inventa el nosotros, el deseo siempre flotante, quién inventa el amor? El deseo se fabrica y el amor es un invento, desde luego. Pero hay más signos: el melodrama y lo cursi se funden con el aura del cuerpo. Aunque por supuesto sea dudoso que el término trovador o bardo nos remita etimológicamente al amor provenzal (lo mismo que, pese a su similitud etimológica, el bolero del XVIII no tiene nada que ver con el bolero actual), lo único cierto es que a veces el bolero, y sobre todo el bolero escrito por mujeres, rompe la imagen romántica del tratamiento de la mujer. Pero recordemos que esa imagen del sentimentalismo, del aura rosa y virginal, es sólo una superestructura, porque lo que en realidad se está vendiendo bajo esa imagen mítica es la imagen de la mujer como "serpara-el matrimonio", típica de la burguesía y de la pequeña burguesía del XIX y de gran parte del XX. En este sentido podemos decir que mientras que el tango es siempre "monista", esto es condensado en sí mismo y no admite fisuras, en el bolero hay siempre diferencia entre lo que se canta y lo que se baila. Y esa distancia la debe rellenar el aura que reverbera en la canción. Algo que se sobreentiende, pero nunca se dice. El bolero -como en cierto sentido el melodrama- es de hecho una combinación compleja de sexo más aura. De biología más "lujo espiritual". De ahí su dualidad impecable e implacable y de ahí que el "aura" del bolero pueda ser no sólo romántica, sino incluso mística: Los Panchos aprovecharon uno de los mejores poemas místicos de Amado Nervo, dedicado a Dios, para convertirlo en un bolero inolvidable: "Si tú me dices ven..." (Titulado Lodo. También "El día que me quieras", de Carlos Gardel y Lepera, es un título de Amado Nervo). Pero por supuesto, el que mejor ha entendido el mundo que subyace al bolero y su atmósfera ha sido una vez más García Márquez, que ha escrito no sólo el mejor bolero de la historia, sino el meta-bolero, el bolero de los boleros, el que los engloba a todos: El amor en los tiempos del cólera. Con ese final fastuoso, cuando el capitán del barco les dice a Él y a Ella: "Y si ahora no nos dejan 
atracar en ningún puerto qué vamos a hacer, cuánto tiempo vamos a estar yendo de una orilla del río a otra". O como lo describe literalmente García Márquez:

El capitán miró a Fermina Daza y vio en sus pestañas los primeros destellos de una escarcha invernal. Luego miró a Florentino Ariza, su dominio impasible, su amor impávido, y lo asustó la sospecha tardía de que es la vida, más que la muerte, la que no tiene límites:

- ¿Y hasta cuándo cree usted que podemos seguir en este ir y venir del carajo? -preguntó.

Florentino Ariza tenía la respuesta preparada desde hacía cincuenta y tres años, siete meses y once días con sus noches:

-Toda la vida, dijo.

2.- Toda una vida es también, por supuesto, el título de uno de los boleros inolvidables a los que aludo. Pero lo grandioso de García Márquez es haber sabido construir la urdimbre, el espesor de su novela, a través de ese proceso de dualidad inevitable entre aura metafísica e infraestructura biológica (que sólo se cruzan irónicamente, al final, en ese recorrido inacabable del barco, como si al final sólo la fuerza del cólera, la fuerza de la naturaleza -caribeña- obligara al amor a romper los diques de la dualidad). Una dualidad, insisto, inadmisible en el tango. El tango, por el contrario, es siempre unitario, seco, sin aura. No hay diferencia entre lo que se canta y lo que se baila. La letra, la música, la canción y el baile forman un todo inseparable. Y cuando digo todo quiero decir que en el tango se dice y se hace - se canta y se bailatodo. No hay sobrentendidos: su materia textual es transparente. Una metáfora nietzschana o la imagen de Spinoza de las "afecciones del cuerpo y la mente". El tango seduce porque no esconde, porque muestra sin más todas las magias del juego sexual, precisamente como articulación de ritos sin los cuales el sexo carecería de sentido: no es un corporalismo mecánico o "gimnástico" al uso (el espíritu ha muerto, sólo existe el cuerpo); ni un espiritualismo sin asidero. Es, diríamos, una fusión casi freudiana; el fantasma de lo imaginario concentrado en el cuerpo. Un sutil enlace de lo visible y lo invisible: para el tango todo es tango. Está en todos los intersticios y en todos los rincones del cuerpo, del sexo y del barrio... Literalmente está en todas partes. Por eso nos seduce, repito. Hugo Pratt, el extraordinario autor de cómics, creador, sobre todo, y 
como se sabe, del fabuloso Corto Maltés, no ha podido olvidar nunca en su obra el impacto que le produjo el tango durante sus años de residencia en Argentina. Y así, además de una serie titulada explícitamente Tango, en el primer volumen de Corto Maltés (La Balada del Mar Salado) nos ha dejado una de las mejores imágenes de esta relación visible/ invisible de la atracción entre deseos, que supone el tango. Dice Corto a Pandora: "Vaya qué guapa. No sé por qué me recuerdas a alguna que escuché en el cabaret de la Parda Flora en Buenos Aires." Pandora: “A lo mejor me parezco a alguna que había allí." Corto: "No. Precisamente porque no te pareces a ninguna. Me gustaría encontrarte siempre... en cualquier lugar...como al tango".

3.- Como al tango, en efecto. Aunque hay que tener en cuenta que el tango que nos ha llegado "esta vez" es ya el tango instrumental, el tango subido al atril. El de los grandes compositores que "instrumentalizaron" el tango a partir de los años cuarenta en un arco que podía oscilar desde la acentuación de la tensión popular hasta el dodecafonismo -incluido el influjo de las orquestas de jazz norteamericanas-. Es el caso de Greco, Canaro, Di Caro, Astor Piazzola, Aníbal Troilo, Salgán, Rovira, y del hasta hace poco vivo -lo sigue estando- Osvaldo Plugiese, el más radicalmente "popular" (junto con Piazzola y Troilo) de este tango compuesto para orquesta: así en dos obras básicas suyas, como Negracha o La Yumba, contestó rapidísimo: “Sí. Es un tango al que se me olvidó ponerle la letra". La respuesta más inteligente, sin duda, para los que le reprochaban la "orquestación". El "aire" del tango, su ráfaga, seguía siendo lo importante... Sólo que al volver de nuevo de la música a la letra, el tango todavía nos reserva más sorpresas. Las letras del tango clásico, en tanto que empapadas en (y herederas de) el modernismo poético son, como el propio Rubén, un archivo y una arqueología recuperadora, a la vez, de viejos ritmos poéticos que habíamos creído perdidos para siempre. Así ocurre, por ejemplo, cuando se escucha el ritmo del verso del Arte Mayor castellano del siglo XV ¡cantado en un tango! El Arte Mayor, ya se sabe, aquel tipo de verso que se inventaron Juan de Mena, Santillana, etc., como soporte de una poesía claramente docta y superior, tanto por su doctrina como por su ritmo. Un ritmo, a su vez, marcado por un peso acentual verdaderamente aplastante (que obligaba incluso a la consideración un tanto despectiva de Menéndez Pelayo): cada verso dividido en dos hemistiquios, en cada uno de los cuales actúa un único núcleo rítmico (donde la primera sílaba no cuenta) formado en realidad por dos sílabas tónicas 
separadas por otras dos átonas (ó o o ó). Cada hemistiquio podía tener entre cinco y siete sílabas, y el verso como tal el doble, como es lógico, aunque la versión más frecuente es la de doce sílabas. Así, el caso quizás más conocido, en el inicio de Las Trescientas de Mena: "Al muy prepotente/ don Juan el Segundo". Pues bien: este artificiosísimo instrumento rítmico, este verso pensado por y para los doctos, para las doctrinas y los razonamientos alegóricos más sutiles del siglo $\mathrm{XV}$, había muerto prácticamente, en tanto que género, en el propio XV (hay algunas reapariciones esporádicas posteriores) hasta anteayer mismo: quiero decir, hasta que lo vemos revivir cantando en el triste encuentro (que es de hecho un desencuentro) entre una puta y su antiguo amante, ambos solitarios y finales: "sus ojos azules/muy grandes se abrieron" (en el tango Llegó una noche).

4.- Se mire como se mire, se trata de un asunto donde la fascinación nos arrastra: el dodecasílabo del Arte Mayor de Mena convertido en "vulgar reptil de lupanar" (como llamó Leopoldo Lugonés al tango). La conversión de "Al muy prepotente don Juan el Segundo" en el son de barrio bajo ("sus ojos azules muy grandes se abrieron") es indudablemente una conversión milagrosa, un milagro increíble si no fuera porque sucede en el interior del tango.

Sin Rubén, evidentemente, todo esto no hubiera podido realizarse, pero sin el tango el dodecasílabo no hubiera bajado a la calle para ser manoseado y sudado como una canción que es un cuerpo. Y es más curioso aún pensar que el Arte Mayor se creó precisamente, para no ser cantado.

Pero es que en el tango ya se sabe que puede suceder de todo: siempre, en cualquier lugar... y en cualquier parte. Ya lo apostillaba magistralmente Borges en Hombre de la esquina rosada. Y por eso concluye: "Vayan abriendo cancha, señores, que la llevo dormida. Dijo, y salieron sien con sien, como en la marejada del tango, como si los perdiera el tango."

Borges también es el tango, en efecto. Y son unos versos suyos la, quizá, mejor aproximación al tema, la que podríamos elegir como definición última: “esa ráfaga el tango, esa diablura”. Sin hablar de Malena, porque ella sólo sabe cantar el tango como 
ninguna... 20

Aunque por supuesto jamás nos podamos olvidar de los "cincuenta y tres años, siete meses y once días con sus noches" del bolero. Es decir: Toda una vida. O quizá sólo el instante, la iluminación de los cuerpos "que hablan", como Bogart e Ingrid Bergman mientras bailaban Perfidia en Casablanca.

“La perfidia de tu amor...” ¿No es el mejor síntoma -en silencio- para el desgarro del bolero? ¿De tu amor o del amor?

(Artículo recibido: 16-11-2010; aceptado: 30-11-2010)

${ }^{20}$ Vid. Granada Tango, op. Cit., pp. 130-133. 